\title{
Applied Electronics and Optical Laboratory: an optimized practical course for comprehensive training on optics and electronics
}

Kaiwei Wang, Xiaoping Wang

Kaiwei Wang, Xiaoping Wang, "Applied Electronics and Optical Laboratory: an optimized practical course for comprehensive training on optics and electronics," Proc. SPIE 10452, 14th Conference on Education and Training in Optics and Photonics: ETOP 2017, 104522V (16 August 2017); doi: 10.1117/12.2269927

Event: 14th Conference on Education and Training in Optics and Photonics, ETOP 2017, 2017, Hangzhou, China 


\title{
"Applied Electronics and Optical Laboratory"- an optimized
}

\section{practical course for comprehensive training on optics and}

\author{
electronics
}

\author{
Kaiwei Wang, Xiaoping Wang \\ College of Optical Science and Engineering, Zhejiang University, Hangzhou 310027, P. R. China
}

In order to enhance the practical education and hands-on experience of optoelectronics and eliminate the overlapping contents that previously existed in the experiments section adhering to several different courses, a lab course of "Applied Electronics and Optical Laboratory" has been established in the College of Optical Science and Engineering, Zhejiang University. The course consists of two sections, i.e., basic experiments and project design. In section 1, basic experiments provide hands-on experience with most of the fundamental concept taught in the corresponding courses. These basic experiments including the study of common light sources such as He-Ne laser, semiconductor laser and solid laser and LED; the testing and analysis of optical detectors based on effects of photovoltaic effect, photoconduction effect, photo emissive effect and array detectors. In section 2, the course encourages students to build a team and establish a stand-alone optical system to realize specific function by taking advantage of the basic knowledge learned from section 1 . Through these measures, students acquired both basic knowledge and the practical application skills. Moreover, interest in optical science has been developed among students.

Key words: practical course, optical instrumentation, sensor

\section{Introduction}

To improve the students' abilities of applying knowledge and hands-on practice, as well as to broaden thinking and cultivate innovative spirits, we establish a new compulsory lab course in the College of Optical Science and Engineering. Through the series of experimental training, students should be able to understand the principle and application of light sources (including gas lasers, semiconductor lasers and solid-state lasers, etc.), radiometry, detectors (photo diode, phototransistor, avalanche photodiode, etc.), and microprocessor. The course is

\footnotetext{
14th Conference on Education and Training in Optics and Photonics: ETOP 2017, edited by Xu Liu, Xi-Cheng Zhang, Proc. of SPIE Vol. 10452, 104522V - (C) 2017 ICO, IEEE, OSA, SPIE CCC code: $0277-786 X / 17 / \$ 18 \cdot$ doi: $10.1117 / 12.2269927$
} 
also envisioned to train students' capabilities of designing and building photoelectric detection instrument according to task demands through the project design.

\section{Course design (experimental preparation, experimental form, process and test, experimental report, assessment methods)}

\subsection{The requirement of experimental preparation}

Students need to carefully read the safety regulations before carrying out experiments preview the contents of the experiment and log on the course site for admission test. Students who do not pass the entry test are not allowed to enter the laboratory to carry out experiments.

\subsection{Experimental form and cooperation}

The 3 credits course includes 16 hours of instruction and 64 hours of experiment. The 16 hours of theoretical teaching includes the knowledge related to experimental content and the introduction of experimental notes, experimental principles, etc. The experimental session is divided into 32 hours of basic experiments and 32 hours of project design (comprehensive experiment). Teachers open the laboratory and guide experiment, and 3 students in a group (random combination) complete the experiments.

The project design is completed by a group of three (or two) students, and each subject can be chosen by a maximum of three groups (the early applicants have priority), reimbursable components procurement funds up to 300 yuan (subject to invoices and purchase list).

\subsection{Experimental process and test}

Conscientiously complete and think about each of the phenomena and problems that occur during the experiment, and use theoretical knowledge to explain the experimental principles.

At the end of the experiment, each student must immediately complete an experimental 
process test, and immediately check the understanding of the content, process and results of the experiment.

Encourage collaboration: Discussing issues with team members will help everyone. However, blatant reproduction and other forms of deception are intolerable, and the teacher will punish such acts.

\subsection{Experimental report or project summary}

Students who attend the course experiment: Write an experimental report and upload the lab report to the course website before the deadline. If there is a personal situation that results in late submission, students must explain it in advance to the teacher.

Students who attend the project design: Participate in the opening defense, mid-term progress report and the final defense, complete the corresponding PPT according to the requirements, and each defense accounts for a certain score. At the end of the project, submit the design documents.

\subsection{Marking scheme}

The experimental course is set up independently, and the experimental score is the final score (the total score). There are two parts: 1) course experimental module 50 points 2) project design module 50 points.

1) Course experimental module (50 points), includes:

- experimental process and the completion: $\quad 60 \%$

(A part of scores are given by the test of experimental process)

$\checkmark$ experiment report: $\quad 20 \%$

(Includes a full experimental report and other simplified experimental reports)

final experiment test: $\quad 20 \%$

(Experimental theory and experimental design)

2) Project design module (50 points), includes:

the progress of project design (opening and mid-term inspection) $15 \%$ 
- the completion of project design (considering the difficulty)

$60 \%$

final defense, report and introduction DV

$25 \%$

3) Additional points (bonus points):

$5 \%$

(Reward distinct creative projects, creative suggestions, project design novelty, scientific papers, patent application and putting forward projects for the future students, etc.)

\section{Experiment course content and allocation of hours}

\subsection{Routine experiment content ( 3 students / group)}

\begin{tabular}{|c|c|c|c|c|}
\hline Name of experiment & Content of experiment & $\begin{array}{c}\text { Allocatio } \\
\text { n of } \\
\text { hours }\end{array}$ & $\begin{array}{c}\text { Type of } \\
\text { experime } \\
\text { nt }\end{array}$ & $\begin{array}{c}\text { Require } \\
\text { ments of } \\
\text { experim } \\
\text { ent }\end{array}$ \\
\hline $\begin{array}{c}\text { Experiment } 1 \\
\text { Photodetector and } \\
\text { Photoconductive Detector } \\
\text { Circuit and its } \\
\text { Characteristic } \\
\text { Measurement }\end{array}$ & $\begin{array}{l}\text { 1. Photodiode test } \\
\text { 2. Photoelectric transistor test } \\
\text { 3. Light characteristics } \\
\text { 4. Volt-Ampere characteristics } \\
\text { 5. The test results are converted by the A/D } \\
\text { converter and then displayed } \\
\text { 6. Set up the test system for LED light intensity } \\
\text { distribution test }\end{array}$ & 4 & Basics & Compulsory \\
\hline $\begin{array}{c}\text { Experiment } 2 \\
\text { The Principle and Driving } \\
\text { Experiment of Area Array } \\
\text { CCD }\end{array}$ & $\begin{array}{l}\text { 1. The method of measuring the waveform, } \\
\text { frequency, period and phase of the vertical and } \\
\text { horizontal driving pulses of the array CCD } \\
\text { 2. Measurement of line, field self scanning TV } \\
\text { system of area array CCD } \\
\text { 3. Measurement of video output signals }\end{array}$ & 4 & Basics & Compulsory \\
\hline $\begin{array}{c}\text { Experiment } 3 \\
\text { LCD }\end{array}$ & $\begin{array}{l}\text { 1. LCD read and write timing and instructions } \\
\text { 2. LCD programming }\end{array}$ & 4 & Basics & Compulsory \\
\hline
\end{tabular}

Proc. of SPIE Vol. 10452 104522V-4 


\begin{tabular}{|c|c|c|c|c|}
\hline $\begin{array}{c}\text { Experiment } 4 \\
\text { Rotating Speed } \\
\text { Measurement and Control }\end{array}$ & $\begin{array}{l}\text { 1. Use photoelectric tube to achieve the click } \\
\text { speed measurement } \\
\text { 2. Use the microcontroller and LCD to display the } \\
\text { measurement results in real time } \\
\text { 3. Use the PID control to adjust the click speed }\end{array}$ & 4 & & \\
\hline $\begin{array}{l}\text { Experiment } 5 \\
\text { Measurement of Line Width } \\
\text { and Output Spatial } \\
\text { Distribution of He-Ne Laser }\end{array}$ & $\begin{array}{l}\text { 1. Laser line width } \\
\text { 2. Laser output spatial distribution CCD } \\
\text { measurement }\end{array}$ & 4 & Basics & Compulsory \\
\hline $\begin{array}{c}\text { Experiment } 6 \\
\text { Characteristics of } \\
\text { Semiconductor Laser and } \\
\text { its Spectral Characteristics }\end{array}$ & $\begin{array}{l}\text { 1. Semiconductor laser safe operation } \\
\text { 2. Measurement of working characteristics of } \\
\text { semiconductor } \\
\text { 3. Measurement of fluorescence spectra and laser } \\
\text { spectra of semiconductor } \\
\text { 4. Far-field distribution measurement of slow-axis } \\
\text { direction of semiconductor } \\
\text { 5. Far-field distribution curve of semiconductor } \\
\text { 5. Measurement of near-field distribution in } \\
\text { slow-axis of semiconductor }\end{array}$ & 4 & Basics & Compulsory \\
\hline $\begin{array}{c}\text { Experiment } 7 \\
\text { Solid-state Laser Nd: YAG } \\
\text { Laser Integrated } \\
\text { Experiments } \\
\text { (Including cavity length } \\
\text { adjustment, cavity type } \\
\text { transformation, beam } \\
\text { quality, cavity length and } \\
\text { power relationship, cavity } \\
\text { frequency and other } \\
\text { experiments.) }\end{array}$ & $\begin{array}{l}\text { 1. Construction of Nd: YVO4 Laser } \\
\text { 2. Intracavity frequency doubling, frequency } \\
\text { doubling condition and efficiency observation } \\
\text { 3. Cavity length adjustment; cavity type } \\
\text { transformation's affect on power } \\
\text { 4. Measure the relationship between cavity length } \\
\text { and power } \\
\text { 5. Beam quality measurement } \\
\text { 6. The use of the data processing program Origin } \\
6.0\end{array}$ & 8 & Basics & Compulsory \\
\hline
\end{tabular}

\subsection{Course Design}

Each year there will be some reference topics released, combined with

Optical-Science-Technology Competition, scientific research and production in the photoelectric technology. Groups of students need to perform researching technologies, determining the program, building the system, contrast test and the final project reply. It is aimed to train the student's skills to solve practical problems. 


\begin{tabular}{|c|c|c|}
\hline No. & Title & Function realization \\
\hline 1 & $\begin{array}{l}\text { An Airborne Rescue } \\
\text { Unmanned Aerial Vehicle } \\
\text { Based on Optoelectronic } \\
\text { Target Recognition }\end{array}$ & $\begin{array}{l}\text { Design an unmanned aerial vehicle for airborne rescue based on } \\
\text { photoelectric target identification. Requirements: use optoelectronic } \\
\text { technology to find the target, and throw the table tennis ball, which is } \\
\text { simulated as relief supplies, to the receiving basket. The amount of } \\
\text { correctly thrown table tennis ball in specified time determines the results } \\
\text { of the contest. }\end{array}$ \\
\hline 2 & $\begin{array}{l}\text { The best imaging system } \\
\text { constructed by single lens }\end{array}$ & $\begin{array}{l}\text { Using the given biconvex lens and CMOS image sensor, make advantage of } \\
\text { photoelectric and image processing technology to build the best imaging } \\
\text { system. }\end{array}$ \\
\hline 3 & $\begin{array}{l}\text { Security monitoring system } \\
\text { in Large space }(50 \mathrm{~m} * 50 \mathrm{~m})\end{array}$ & $\begin{array}{l}\text { Design a security system for large warehouses, which requires the ability to } \\
\text { detect anomalous intruders in time and to obtain clear face images and } \\
\text { transmit images to remote terminals (computers or mobile phones) and } \\
\text { alert them. }\end{array}$ \\
\hline 4 & $\begin{array}{l}\text { Photoelectric distance } \\
\text { measurement }\end{array}$ & Measure the distance between the workpiece and another. \\
\hline 5 & $\begin{array}{l}\text { Shaft diameter measuring } \\
\text { device }\end{array}$ & Measure the diameter of rod-like, linear or tubular workpieces. \\
\hline 6 & $\begin{array}{l}\text { Space visible light } \\
\text { communication }\end{array}$ & $\begin{array}{l}\text { Space information transmission. You can use laser, white light to pass a } \\
\text { voice, music, or information coding. }\end{array}$ \\
\hline 7 & $\begin{array}{l}\text { Photoelectric intelligent } \\
\text { infusion detector }\end{array}$ & To determine whether the infusion ends and alarm. \\
\hline 8 & Photoelectric thermometer & Measure objects or body temperature. \\
\hline 9 & $\begin{array}{l}\text { Photoelectric velocity } \\
\text { measurement }\end{array}$ & Measure moving object speed and alarm. \\
\hline 7 & Photoelectric name system & $\begin{array}{l}\text { Use optical face, eye recognition or fingerprint recognition to achieve } \\
\text { automatic naming. }\end{array}$ \\
\hline 8 & $\begin{array}{l}\text { Optical signal simulation } \\
\text { carrier }\end{array}$ & $\begin{array}{l}\text { An optical signal is used as a carrier signal to perform analog signal } \\
\text { transmission such as audio. }\end{array}$ \\
\hline 9 & Optical listening & Use the active light source for audio signal monitoring \\
\hline 10 & Automatic patrol car & A car that is able to identify the 8-shaped lane line and move along the line. \\
\hline
\end{tabular}

Proc. of SPIE Vol. 10452 104522V-6 


\subsection{Conclusion}

A new course of Applied Electronics and Optical Laboratory has been established the College of Optical Science and Engineering, Zhejiang University, in order to enrich the hands-on experience and a of optical instrumentation, microprocessor, electronics and computer programming. The course includes a basic experiments module and a project design module. Basic experiments provide hands-on experience with most of the fundamental concept taught in the corresponding courses. In the project design module, students are encouraged to establish a stand-alone optical system to realize specific function by taking advantage of the basic knowledge learned from section 1 . Through these measures, students acquired both basic knowledge and the practical application skills. 